\title{
UJI KERENTANAN NYAMUK Aedes aegyptiTERHADAP LAMDA SIHALOTRIN DAN SIPERMETRIN TAHUN 2016
}

\author{
Yulistra Naftali Eka Putra, Koerniasari, Mamik
}

\begin{abstract}
Dengue Hemorrhagic Fever (DHF) in Indonesia is an endemic disease with morbidity level tends to increase from year to year and extends to 400 regencies/cities from 474 regencies/cities in Indonesia. This disease even frequently causes Outbreaks (KLB). One of the dengue controls is chemical control. Chemical control by using insecticides is the most popular form of control in the society because it is easy to implement. Insecticides are most commonly used are lambda cyhalothrin and sipermetrin because it is cheap and readily available. The use of the same insecticide for around 2-20 years and improper dosage can cause mosquitoes to become resistant.

This study aimed to test the susceptibility of mosquitoes to Lamdacyhalothrin and cypermethrin. This research was experimental and the study design used "with Pretest-Posttest Control Group". Susceptibility Test used 500 Aedesaegypti mosquito as sample and using 20 tubes with ach tube is filled 25 mosquitoes. $0.05 \%$ of Lamdacyhalothrin and $0.05 \%$ of cypermethrin were put in 8 tubes while for control was 4 tubes containing plain white paper. Mosquitoes were exposed for 1 hour, then transferred into paper cup containing cotton containing sugar water, then stored for 24 hours. The observation was then carried out and calculating the percentage of dead mosquitoes.

The results showed the number of dead mosquitoes with Lamdacyhalothrin was $7 \%$, included in the category of resistance (WHO). The number of dead mosquitoes with cypermethrin was $2.5 \%$ which is also in the category of resistance. This susceptibility status categories are taken based on the criteria of the WHO, the mortality $<80 \%$ means resistant, the mortality of $80-97 \%$ are tolerant, and $98 \%-100 \%$ is susceptible (WHO, 1975)
\end{abstract}

The society is advised to use insecticide in the right dose, limiting the excessive use of insecticides and if necessary, only to use non-chemical control.

Keywords : Aedes aegypti, Suceptibility Test, Lamdacyhalothrin, Cypermethrin

\section{PENDAHULUAN}

Penyakit DBD di Surabaya, Jakarta jumlah kasus terus bertambah seiring semakin meluasnya daerah endemis. Penyakit ini tidak hanya sering menimbulkan KLB tetapi menimbulkan dampak buruk sosial maupun ekonomi. Kerugian sosial yang terjadi antara lain karena menimbulkan kepanikan dalam keluarga, kematian anggota keluarga, dan berkurangnya usia harapan penduduk. (Kemenkes RI, 2011)

Penggunaan insektisida secara terus menerus akan menimbulkan dampak negatif dengan matinya organisme bukan sasaran, adanya residu sehingga terjadi pencemaran lingkungan serta timbulnya resistensi. Faktor lain penyebab resistensi adalah penggunaan dosis yang rendah (under dose) atau dosis yang tidak mematikan (Tarumingkeng, 1992).

Menurut Dyah Widiastuti terjadinya resistensi dipengaruhi beberapa faktor, terutama pengunaan insektisida dalam waktu yang lama (sekitar 2 - 20 tahun) dan dosis yang tidak tepat. Faktor pendukung terjadi-nya resistensi adalah penggunaan insektisida sama atau sejenis secara terus menerus, penggunaan bahan aktif atau formulasi mempunyai aktifitas sama, efek residual lama dan biologi spesies vektor. Penyemprotan residual memberi peluang lebih besar menciptakan generasi resisten dibandingkan dengan cara aplikasi lain, karena peluang kontak antara vektor dengan bahan aktif lebih besar. Faktor pendukung lainnya adalah penggunaan insektisida yang sama terhadap semua stadium pertumbuhan vektor (telur, larva, pupa dan dewasa). Oleh karena itu, untuk mencegah dan mengurangi terjadinya percepatan resistensi, sebaiknya tidak menggunakan insektisida dari jenis dan atau golongan insektisida yang cara kerjanya sama untuk pengendalian stadium pra-dewasa dan dewasa.

Resistensi populasi nyamuk di lapangan hampir selalu mengandung beberapa heterogenitas, dan rentan terus menyusup dari daerah sekitar yang tidak terpapar insektisida. Pada nyamuk, resistensi terutama dihubungkan dengan modifikasi sisi target dan ketahanan metabolik.

Insektisida yang paling sering digunakan adalah Lamda Sihalotrin dan 
Sipermetrin. Kelebihan Lamda Sihalotrin adalah menghemat biaya pengendalian, tidak berbau, tidak meninggalkan bekas pada permukaan yang disemprot dan mudah menggunakannya. Sedangkan kelebihan Sipermetrin adalah murah harganya efektif mengendalikan nyamuk Aedes aegypti dewasa, dosis aplikasi rendah, memiliki toksisitas rendah terhadap mamalia, mudah diaplikasikan dengan pengabutan dan pengasapan. (Sembiring, 2009)

Untuk menguji kerentanan nyamuk di suatu tempat, menggunakan metode Susceptibility Test. Pada saat ini badan dunia mempunyai metode baku susceptibility yang digunakan untuk mendeteksi dan memantau status kerentanan dan telah digunakan untuk beberapa tahun (WHO, 1992). Uji susceptibility dilakukan menggunakan stadium dewasa dari nyamuk uji. (Dani S, 2011). Data resistensi sangat diperlukan sebagai bahan pertimbangan untuk dilakukan kegiatan pengendalian vektor DBD. Sangatlah penting untuk selalu memonitor resistensi selama kegiatan pengendalian masih dilaksanakan (Yanuar Firda, 2011). Hasil penelitian diharapkan dapat memberikan informasi dasar dalam tata laksana pengendalian nyamuk Aedes aegypti dengan insektisida yang sesuai.

Penelitian ini bertujuan untuk mengetahui tingkat kerentanan nyamuk Aedes aegypti dewasa terhadap Lamda Sihalotrin dan Sipermetrin.

\section{METODE PENELITIAN}

Jenis penelitian ini eksperimen murni bertujuan untuk mengetahui jumlah nyamuk yang rentan terhadap Lamda Sihalotrin dan Sipermetrin. Penelitian ini merupakan penelitian laboratorium. Desain penelitian menggunakan "Pretest-Postest with Control Group". Dalam rancangan ini hanya menggunakan kelompok subjek. perlakuan dalam jangka waktu tertentu, kemudian dilakukan pengukuran kembali.

\section{hASIL PENELITIAN DAN PEMBAHASAN}

Penelitian ini dilakukan selama dua hari yaitu pada tanggal 13 sampai 14 Juni 2016 di Laboratorium Entomologi Dinas Kesehatan Provinsi Jawa Timur. Penelitian ini bertujuan untuk menguji kerentanan nyamuk Aedes aegypti dewasa terhadap pestisida rumah tangga. Penelitian ini menggunakan insektisida Lamda Sihalotrin dan Sipermetrin. Pertimbangan menggunakan kedua insektisida ini karena mudah didapatkan oleh masyarakat, memiliki daya toksisitas efektif untuk membunuh nyamuk Aedes aegypti dewasa, memiliki daya toksisitas rendah terhadap mamalia dan mudah diaplikasikan di lapangan.
Uji kerentanan (Suceptibility test) ini menggunakan kertas yang mengandung insektisida (Impregnated paper) berbahan aktif Lamda Sihalotrin 0,05\% dan Sipermetrin $0,05 \%$. Tabung yang digunakan berjumlah 20 pasang tabung dengan rincian yaitu, 8 pasang tabung untuk Lamda Sihalotrin 0,05\%; 8 pasang untuk Sipermetrin 0,05\% dan untuk kontrol yaitu 4 pasang tabung yang tidak berisi kertas mengandung pestisida.

Uji kerentanan (Susceptibilty test) ini menggunakan sampel 500 nyamuk uji Aedes aegypti dewasa dengan rincian yaitu, 200 ekor dipaparkan Lamda Sihalotrin 0,05\%; 200 ekor dipaparkan Sipermetrin 0,05\% dan 100 ekor untuk kontrol.

Pelaksanaan uji kerentanan (Susceptibilty test) pertama yaitu Siapkan 16 tabung bertanda hijau (holding tube). Ambil nyamuk Aedes aegypti dewasa yang telah dikembangbiakkan pada generasi ketiga dari kandang perkembangbiakan, menggunakan aspirator. Untuk masing-masing tabung diisi 25 ekor nyamuk uji Aedes aegypti dewasa. Selanjutnya Siapkan tabung bertanda merah (exposure tube), masing-masing 8 tabung yang terisi kertas insektisida Lamda sihalotrin 0,05\% dan 8 tabung yang telah terisi kertas insektisida Sipermetrin 0,05\%. Pasang masing-masing tabung bertanda hijau yang berisi nyamuk Aedes aegypti dewasa ke masing-masing tabung bertanda merah yang berisi kertas insektisida. Jika semua nyamuk uji sudah berpindah semua ke tabung bertanda merah, tutup slide. Lakukan pada semua tabung. Paparkan selama 1 jam. Catat suhu dan kelembaban selama pemaparan. Pindahkan nyamuk uji Aedes aegypti dewasa yang telah dipaparkan, ke dalam paper cup yang telah berisi kapas mengandung larutan gula menggunakan aspirator. Simpan paper cup berisi nyamuk uji selama 24 jam. Setelah penyimpanan selama 24 jam, nyamuk diperiksa dan dihitung berapa yang mati dan yang hidup. Hasil pengamatan dicatat dalam lembar observasi. Kemudian hitung persentase nyamuk uji yang mati. Dari persentase kematian tersebut dapat dikategorikan dalam 3 kategori yang telah ditentukan oleh WHO. Menurut WHO, jika persentase kematian $<80 \%$ dikategorikan resisten, persentase kematian antara $80 \%$ - $97 \%$ dikategorikan toleran dan persentase kematian antara 98\% - 100\% dikategorikan rentan.

Apabila kematian nyamuk kontrol 5 $20 \%$, maka untuk faktor koreksi harus digunakan rumus ABBOT'S. Dan bila kematian nyamuk kontrol lebih besar dari $20 \%$ maka pengujian tersebut dinyatakan gagal dan harus diulang kembali. 
1. Perhitungan jumlah Nyamuk Aedes aegypti dewasa yang mati terhadap Lamda Sihalotrin 0,05\% dan Sipermetrin 0,05\%.
Hasil pengamatan dan perhitungan jumlah nyamuk yang rentan terhadap Lamda Sihalotrin $0,05 \%$ dan Sipermetrin $0,05 \%$ yang dapat ditunjukan pada tabel 1 berikut:

Tabel 1

Hasil Pengamatan dan Perhitungan Laboratorium Jumlah Nyamuk Aedes aegypti yang Mati

\begin{tabular}{|c|c|c|c|c|c|}
\hline \multicolumn{6}{|c|}{ Jenis Insektisida } \\
\hline \multicolumn{3}{|c|}{ Lamda Sihalotrin $0,05 \%$} & \multicolumn{3}{|c|}{ Sipermetrin $0,05 \%$} \\
\hline \multirow{2}{*}{ Tabung ke- } & \multicolumn{2}{|c|}{ Jumlah nyamuk yang mati } & \multirow{2}{*}{ Tabung ke- } & \multicolumn{2}{|c|}{ Jumlah nyamuk yang mati } \\
\hline & Uji & Kontrol & & Uji & Kontrol \\
\hline 1 & 3 & 0 & 1 & 1 & 0 \\
\hline 2 & 1 & 0 & 2 & 0 & 0 \\
\hline 3 & 3 & 0 & 3 & 0 & 0 \\
\hline 4 & 0 & 0 & 4 & 1 & 0 \\
\hline 5 & 2 & 0 & 5 & 2 & 0 \\
\hline 6 & 1 & 0 & 6 & 1 & 0 \\
\hline 7 & 3 & 0 & 7 & 0 & 0 \\
\hline 8 & 1 & 0 & 8 & 0 & 0 \\
\hline Jumlah & 14 & 0 & Jumlah & 5 & 0 \\
\hline
\end{tabular}

Sumber: Data Primer 2016

$\begin{array}{ll}\text { Suhu } & : 28^{\circ} \mathrm{C} \\ \text { Kelembaban } & : 68 \%\end{array}$

Data penelitian diperoleh dengan menghitung angka kematian nyamuk uji maupun kontrol setelah dipaparkan insektisida Lamda Sihalotrin 0,05\% dan insektisida Sipermetrin 0,05\% selama kurun waktu 1 jam yang kemudian disimpan pada paper cup selama 24 jam. Pada setiap tabung diisi 25 ekor nyamuk. Jumlah nyamuk uji Aedes aegypti dewasa yang dipaparkan insektisida Lamda Sihalotrin 0,05\% berjumlah 200 ekor.

Jumlah tersebut sama dengan jumlah nyamuk uji Aedes aegypti dewasa yang dipaparkan insektisida Sipermetrin 0,05\% yaitu, 200 ekor.

2. Perhitungan Analisis persentase Nyamuk Aedes aegypti yang mati terhadap insektisida Lamda Sihalotrin 0,05\% dan Sipermetrin 0,05\%

Indikator variabel resistensi dihitung dengan rumus:

$(\%)=\frac{\text { Jumlah } 1 \text { yamukyang mati }}{\text { JumlahHyamukkeseluruhar }} \times 100$

a. Lamda Sihalotrin $0,05 \%$

(\%) Kematian terhadap Lamda Sihalotrin $=\frac{\mathbb{1 4}}{200} \times 100=7 \%$

Dari perhitungan persentase kematian nyamuk uji Aedes aegypti dewasa terhadap Lamda Sihalotrin 0,05\% diperoleh hasil persentase kematian sebesar 7\%. Hal ini menunjukkan bahwa nyamuk uji dikategorikan resisten. Menurut WHO (1975), jika persentase

b. Sipermetrin $0,05 \%$

(\%) Kematian $=\frac{5}{200} \times 100=2,5 \%$
Pada tabel 1 diatas menunjukkan jumlah angka nyamuk uji yang mati pada saat penyimpanan. Hasil perhitungan angka nyamuk uji yang mati terhadap Lamda Sihalotrin 0,05\% menunjukan sebanyak 14 ekor dari 200 ekor nyamuk Aedes aegypti dewasa yang diuji. Sedangkan untuk jumlah angka nyamuk uji yang mati terhadap Sipermetrin 0,05\% sebanyak 5 ekor dari 200 ekor nyamuk Aedes aegypti dewasa. Dan untuk kontrol tidak ada yang mati sehingga tidak perlu menggunakan Rumus ABBOT'S sebagai faktor koreksi. kematian nyamuk uji kurang dari $80 \%$ dikategorikan resisten. Resisten adalah kemampuan individu serangga untuk bertahan hidup terhadap suatu dosis insektisida dalam keadaan normal dapat membunuh spesies serangga tersebut (Dani S, 2011). 
Dari perhitungan persentase kematian nyamuk uji Aedes aegypti dewasa terhadap Sipermetrin 0,05\% diperoleh hasil persentase kematian sebesar 2,5\%. Hal ini menunjukkan bahwa nyamuk uji dikategorikan resisten. Menurut WHO (1975), jika persentase nyamuk uji yang mati kurang dari $80 \%$ dikategorikan resisten.

Hasil dari uji kerentanan (Susceptibility test) nyamuk Aedes aegypti dewasa yang dikembangbiakan sampai pada generasi ke-3 dengan menggunakan insektisida berbahan aktif Lamda Sihalotrin 0,05\% menunjukkan bahwa nyamuk uji dikategorikan resisten terhadap insektisida tersebut. Hal ini ditunjukan dengan hasil perhitungan persentase kematian nyamuk uji yang hanya sebesar $7 \%$. Hal yang sama juga terlihat dari hasil uji yang menggunakan insektisida berbahan Sipermetrin 0,05\%. Ditunjukan dengan hasil persentase kematian nyamuk uji sebesar 2,5\% yang artinya sudah termasuk dalam kategori resisten. Resisten adalah kemampuan individu serangga untuk bertahan hidup terhadap suatu dosis insektisida yang dalam keadaan normal dapat membunuh spesies serangga tersebut (Dani S, 2011).

Status resistensi atau kerentanan insektisida (insecticide susceptibility) terhadap serangga, diukur menggunakan prosedur standar tes kerentanan, yaitu metode standar yang tepat untuk mengukur resistensi insektisida khususnya di lapangan.

Kategori status kerentanan ini diambil berdasarkan kriteria dari $W H O$, yaitu kematian < $80 \%$ termasuk resisten, kematian $80-97 \%$ termasuk toleran, dan $98 \%$ - $100 \%$ termasuk rentan. (WHO, 1975).

Resistensi adalah kemampuan individu serangga untuk bertahan hidup terhadap suatu dosis insektisida yang dalam keadaan normal dapat membunuh spesies serangga tersebut. Resistensi merupakan suatu fenomena evolusi yang disebabkan oleh seleksi serangga hama yang diberi perlakuan insektisida secara terus menerus.

Untuk mendeteksi resistensi vektor terhadap insektisida dilakukan pencarian dan penemuan vektor yang menunjukkan tandatanda toleransi atau yang berpotensi resisten. Deteksi dini berupa surveilanse vektor yaitu dengan melakukan aplikasi insektisida secara berulang-ulang atau lebih dari 3 tahun. Upaya lanjutan dalam penggunaan insektisida kimia adalah dilakukannya pemantauan (monitoring)

3. Hasil Perhitungan Rasio nyamuk Aedes aegypti yang mati terhadap insektisida resistensi vektor terhadap insektisida tersebut. Jika terbukti bahwa proporsi populasi nyamuk sasaran resisten telah lebih dari $50 \%$, penggunaan insektisida tersebut harus dihentikan dan dipertimbangkan pengganti atau alternatifnya.

Hal ini terjadi karena ada 3 faktor yang mempengaruhi status kerentanan beberapa serangga termasuk nyamuk, yaitu faktor genetik berupa gen-gen yang dapat merubah enzim esterase dari nyamuk, sehingga dapat menyebabkan resistensi serangga terhadap insektisida baik organofosfat atau piretroid (Lamda Sihalotrin dan Sipermetrin). (Westya, 2015)

Faktor yang kedua adalah faktor biologis meliputi biotik (adanya perkawinan). Karakteristik resistensi insektisida akan diturunkan ke generasi berikutnya. Dalam beberapa kasus telah terbukti faktor resistensi melibatkan perubahan genetik.

Dan yang ketiga adalah faktor operasional, meliputi penggunaan jenis insektisida yang sama atau sejenis dalam kurun waktu yang lama, seringnya frekuensi penggunaan bahan kimia yang digunakan dalam pengendalian vektor, dosis formulasi yang digunakan terlalu tinggi, dan efek residual yang lama karena peluang kontak antara vektor dengan bahan aktif lebih besar.

Jenis resistensi vektor (nyamuk) terhadap insektisida dapat berupa resistensi tunggal, resistensi ganda (multiple resistance) atau resistensi silang (cross resistance).

a. Resistensi tunggal adalah resistensi pada populasi serangga terhadap satu jenis insektisida.

b. Resistensi ganda (multiple resistance) adalah resistensi secara simultan terhadap beberapa insektisida dengan perbedaan kategori insektisida.

c. Resistensi silang (cross resistance) adalah perkembangan resistensi pada populasi serangga termasuk nyamuk akibat penekanan secara selektif insektisida lain dengan mekanisme sama/target site sama, tetapi bukan dari satu kelompok insektisida. (Dani S, 2011). Dari penelitian yang dilakukan dapat dikategorikan dalam jenis resistensi ganda (multiple resistance) karena nyamuk Aedes aegypti yang diuji telah resisten terhadap dua jenis bahan aktif insektisida yang berbeda golongan Sintetik Piretroid yaitu Lamda Sihalotrin dan Sipermetrin.

Lamda Sihalotrin 0,05\% dan Sipermetrin $0,05 \%$ 
Rasio adalah perbandingan dua bilangan yang tidak saling tergantung. Rumus rasio adalah sebagai berikut:

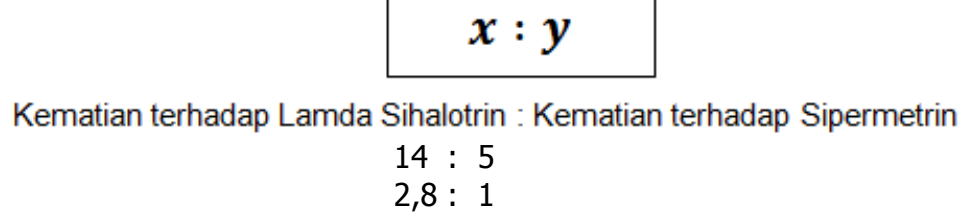

Dari perbandingan rasio jumlah kematian nyamuk uji Aedes aegypti dewasa antara insektisida Lamda Sihalotrin 0,05\% dibanding insektisida Sipermetrin $0,05 \%$ diatas, menunjukkan bahwa insektisida Lamda Sihalotrin 2,8 kali lebih efektif untuk membunuh vektor nyamuk Aedes aegypti daripada insektisida Sipermetrin.

Dari hasil perhitungan rasio atau perbandingan kematian nyamuk uji Aedes aegypti dewasa antara insektisida berbahan aktif Lamda Sihalotrin 0,05\% dan Sipermetrin 0,05\%; menunjukan angka rasio sebesar 2,8 berbanding 1 . Yang artinya penggunaan insektisida berbahan aktif Lamda Sihalotrin 2,8 kali lebih efektif digunakan sebagai pembunuh nyamuk Aedes aegyptidewasadibanding insektisida berbahan aktif Sipermetrin.

\section{KESIMPULAN}

Berdasarkan hasil eksperimen yang telah dilakukan, maka penulis mencoba menarik kesiumpulan sebagai berikut:

1. Nyamuk Aedes aegypti dewasa yang mati terhadap Insektisida berbahan aktif Lamda Sihalotrin 0,05\%berjumlah 14 ekor dari 200 ekor.

2. Nyamuk Aedes aegypti dewasa yangrentan terhadap Insektisida berbahan aktif Sipermetrin 0,05\%berjumlah 5 dari 200 ekor.

3. Hasil Analisis persentase kematian nyamuk Aedes aegypti dewasa terhadap Insektisida

\section{SARAN}

1. Jangan memakai bahan aktif insektisida yang sama secara terus menerus dalam jangka waktu yang lama.

2. Penggunaan insektisida dengan dosis yang tepat.

\section{DAFTAR PUSTAKA}

Chandra, Budiman. 2006. Pengantar Kesehatan Lingkungan. Jakarta. PenerbitBuku Kedokteran EGC

Dani S, Cecep. 2011. Vektor PenyakitTropis. Sleman, Yogyakarta. Gosyen Publishing.

Depkes RI. 2003. Modul EntomologiMalaria.
Insektisida Lamda Sihalotrin termasuk kategori insektisida beracun (moderately toxic) dari golongan piretroid, insektisida ini bersifat Suspected Endocrin Disruptor (SE) dan mampu menghambat metabolisme dan sistem saraf pusat pada nyamuk. Selain itu insektisida ini merupakan racun kontak dan racun perut yang banyak digunakan untuk pengendalian serangga. Insektisida golongan ini tergolong dengan racun golongan rendah bila terpapar melalui kulit, tetapi sangat beracun bila terhirup.

Sedangkan insektisida Sipermetrin merupakan racun perut yang membunuh serangga sasaran bila insektisida tersebut masuk ke dinding saluran pencernaan.

berbahan aktif Lamda Sihalotrin 0,05\%dan Sipermetrin 0,05\%termasuk dalam kategori resisten (kematian < 80\%).

4. Perbandingan efektifitas antara Lamda Sihalotrin 0,05\%dan Sipermetrin 0,05\%didapatkan hasil perbandingan bahwa penggunaan insektisida berbahan aktif Lamda Sihalotrin lebih efektif membunuh nyamuk Aedes aegypti dewasa 2,8 kali lebih besar daripada insektisida yang berbahan aktif Sipermetrin.

3. Penggunaan insektisida hanya pada musim penularan.

4. Penggunaan metode pengendalian nyamuk vektor yang non-kimia saja, atau sebagai tindakan penunjang, pada musim penularan dimana aplikasinya cukup murah dan efektif.

Jakarta. Departemen Kesehatan Republik Indonesia

Ehrenstorfer. 2014. Alphabetical

listingofindividual standards. LGC

www.lgcstandards.com. 3 Februari 2016 
Ikawati, Bina dkk. 2015. Jurnal Petastatus kerentanan Aedes aegypti (Linn.)Terhadap insektisidaCypermethrin dan malathion di Jawa Tengah. Jawa Tengah. Balai Litbang Pengendalian Penyakit Bersumber Binatang (P2B2) Banjarnegara, Badan Penelitian dan Pengembangan Kesehatan, Kementerian Kesehatan Republik Indonesia.http://ejournal.litbang.depkes.g o.id. 25 Januari 2016

Kemenkes RI.

2011.

ModulPengendalianDemamBerdarahDengu e.Jakarta.KementerianKesehatanRepublik Indonesia.

Kemenkes RI. 2012. Pedoman Penggunaan Insektisida (Pestisida) Dalam Pengendalian Vektor. Jakarta. Kementerian Kesehatan Republik Indonesia.

Notoatmojo, Soekidjo. 2010. Metodologi Penelitian Kesehatan. Jakarta. Rineka Cipta.

Sarudji, Didik. 2006. Kesehatan Lingkungan. Surabaya. Media IImu.

Sembel, Dantje T. 2009. Entomologi Kedokteran. Yogyakarta. C.V Andi Offset.

Sembiring, Odentara. 2009. Efektifitas Beberapa Jenis Pestisida Terhadap Nyamuk Aedes aegypti.
Medan.http://repository.usu.ac.id/09E0223 5.pdf. 25 Januari 2016

Soemirat, Juli. 2011. KesehatanLingkungan. Bulaksumur, Yogyakarta. GadjahMada University Press.

Suyono dan Budiman. 2010. IImu Kesehatan Masyarakat Dalam Konteks Kesehatan Lingkungan. Jakarta. Penerbit Buku Kedokteran EGC.

Tarumingkeng, R. C. 1992.Insektisida Sifat, Mekanisme, Kerja dan Dampak Penggunaannya. Jakarta. Ukrida Press.

Widiastuti, Dyahet al. 2015. Aktivitas enzim monooksigenase pada populasi nyamuk Aedes aegypti di Kecamatan Tembalang, Kota Semarang. Semarang. Balai Litbang Pengendalian Penyakit Bersumber Binatang (P2B2) Banjarnegara, Badan Penelitian dan Pengembangan Kesehatan, Kementerian Kesehatan Republik Indonesia.

http://ejournal.litbang.depkes.go.id. 19 Februari 2016.

Yanuar, Firda. 2011. Status Resistensi Aedes aegypti dengan Metode Susceptibility di Kota Cimahi terhadap Cypermethrin. Cimahi.LokaLitbang P2B2 Ciamis, Badan Litbangkes.

http://ejournal.litbang.depkes.go.id.12 Januari 2016. 